\section{The Effect of the Combination of Different Methods of Stock Analysis on Portfolio Performance}

\author{
Vesna Trančar \\ Šolski center Ptuj, Ptuj, Slovenia \\ vesna.trancar@guest.arnes.si
}

\begin{abstract}
The literature that examines the stock analysis is often faced with the same questions: Which stock analyses should be chosen and which indicators of individual stock analyses give the best information on whether a particular stock should be included in the portfolio? How many indicators and which combination of indicators should you choose to forecast future stock prices as accurately as possible? Can investors use stock analyses to create such a portfolio to meet the investment expectations? The main purpose of this article is to use theoretical methodology to determine whether the use of a combination of indicators from different stock analyses has a positive impact on the profitability of the portfolio.
\end{abstract}

Keywords: Portfolio, stock analysis, portfolio manager, indicators, investment decisions, stock prices

\section{Introduction}

Future movements in stock prices can be assessed using a variety of methods and indicators. In the literature, the most commonly represented methods are the fundamental and the technical analyses of stocks. The job of stock market analysts and portfolio managers is to try to find the best method or the best model to forecast future stock prices in a certain period of time as the aforementioned methods and models are constantly updated and supplemented. Of course, it would be irrational if stock analysts continuously used only the current "safest" methods. Unfortunately, the use of graphic examples of stock price movements or the indicators of the fundamental analysis of stocks only does not suffice for a sound method, which could be used to forecast the future stock price movements. However, the results of both simulations shown in this contribution demonstrate that it is the best for using the combination of both types of stock analyses.

\section{Overview of the Theoretical Basis of Fundamental and Technical Analysis of Stocks}

A fundamental analysis argues that the stock price is influenced by many factors, such as the company's profit, the company's reputation, risk degree, the impact of monetary policies, fiscal policies, the impact of macroeconomic aggregates, and the economic cycle phase of the global economy. All of these factors represent basic information for a fundamental analysis of stocks, which does not relate only to the company, but also to the industry and the overall economy. With the data
ORIGINAL SCIENTIFIC PAPER

Received: January 2014

Revised: August 2014

Accepted: August 2014

DOI: 10.1515/ngoe-2015-0004

UDK: $336.76: 330.133 .2: 330.43$

JEL: G30, G31, G32

\section{NG OE}

NAŠE GOSPODARSTVO OUR ECONOMY

\begin{tabular}{l|l|l|} 
Vol. 61 & No.1 2015 \\
\hline
\end{tabular}

pp. $37-50$ 
collected, we can estimate what will happen with regard to the prices of stocks in the future. A fundamental analysis requires a lot of time, as it includes a number of indicators for the analysis of a relatively small number of stocks (Baker, 2010; Braun, 2007; Goldberg \& von Nitzsche, 2000).

The price-to-earnings ratio (P/E ratio) indicator represents the ratio between the market price per stock and net income (earnings) per stock. It is the most frequently used indicator among investors making investment decisions (Kleindienst, 2001; Madura, 2011). By comparing the earnings per stock and dividend per stock, we can also calculate the stock of payments to companies or the payout ratio, which represents the ratio of dividends paid in comparison to the entire net income of the company. Another indicator is the price-tobook ratio ( $\mathrm{P} / \mathrm{B}$ ratio), representing the ratio between the stock price and its book value. Analysts can also use the price-to-sales ratio (P/S ratio), which represents the ratio between the stock price and turnover of the company, to assess the current stock value per stock (Matschke \& Brösel, 2013; Pernsteiner, 2008). The expected success of a company and the expected growth of a company's stock value in the future can also be determined by using indicators such as EBIT and EBITDA ${ }^{1}$ (Born, 2009; Mattern, 2005).

In addition to the fundamental analysis of stocks, financial markets analyses use a slightly newer stocks analysisnamely, the technical analysis of stocks - which, with respect to their observations and forecasts, can sometimes surpass even the fundamental analysis of stocks. The technical analysis uses past prices and other past data to predict future market movements. In practice, all major portfolio managers publish technical commentaries on the market, and many of the advisory services are based on technical analyses (Han, Yang \& Zhou, 2013). Their approach assumes that stock prices move cyclically and that all the facts and the relevant stock price data reflect fluctuations in stock prices. By estimating the movements in stock prices in the past, we can predict future stock market trends. We can presumably use certain information to predict the changes in trends and their continuity. To analyze the formations and trends, the most commonly used techniques are the line, bar, and point and figure charts as well as the Japanese candlestick approach (Nison, 2001; Welcker, 1994), which is why this analysis is also called a chart analysis as it assumes that the purchase signals of individual stocks in the graph can be significantly faster read than through the information available via the use of the fundamental analysis.

The challenge or the art of forecasting price movements of stocks in the future stems from the reliability of chart-reading systems in the close monitoring and assessing of

\footnotetext{
${ }_{1}^{1}$ Earning Before Interest, Taxes, Depreciation and Amortization
}

exchange rate "oscillations." Several tools can be used for these purposes: the trend line and the formations signaling recommendations about buying or selling stocks. The next most commonly used indicator is the moment at which we measure the degree of variability in stocks' trends (Knight, 2007). Another important technical indicator is the relative strength index, an oscillator that compares the output rate at a given moment with the output rate in the past. MACD is an oscillator that measures the relationship between two moving averages of the rate. It shows the difference between 26-day and 12-day exponential moving average rates (Knight, 2007; Steiner \& Bruns, 2008).

Equity analysts and portfolio managers are important information intermediaries (Ellmann, 2006) on the capital market. Their primary role is that, by actively managing investments, they achieve additional value for an investor (Budelmann, 2013). This is why the experts favoring the fundamental analysis underscore the view that, before deciding to purchase stocks, the investor's priority task is to take into consideration the psychological aspects of stock market participants in addition to indicators of fundamental analysis, as this consideration, in their opinion, makes it possible to gather a large amount of relevant data.

In contrast, technical analysts do not deal with the fundamental data of each stock. For each stock, they can accurately describe its position and possible future trends of a corporation, but they do not consider that the movement of the stock price largely depends on the subjective assessments of the investor and stock market participants (Bazdan, 2010; Steiner \& Bruns, 2008). Heese (2011) argued that the comprehensive analysis of stocks necessarily involves the use of indicators from both analyses.

\section{Hypothesis}

Based on the previous discussion, the portfolio manager's decisions about which stocks will be included in the portfolio depend upon a wide range of factors, which are dealt with in detail by the stocks analysis methods already described. When studying the stock analyses, we can argue that both analyses have their strengths and weaknesses; thus, none can be described as "better.,. From our starting point, and given the fact that selecting the right portfolio is a delicate act that plays a decisive role in determining whether we will achieve the desired return or not, this study focuses on verifying the following hypothesis: When we combine the indicators from various stock analyses to include stocks in a portfolio, there is a greater likelihood that the portfolio will be more profitable. The verification of the hypothesis is connected with the risk of obtaining different results when 
other types of stocks are selected-namely, the final result is dependent on the selection of indicators, the chosen time period, stock selection for joint portfolio for the purpose of stock selection, and some additional factors.

\section{Research Methodology}

To test the hypothesis, we used three simulations comprising 20 randomly selected stocks that were monitored for 10 years; next, another three simulations comprising 26 stocks were monitored for a year. The stocks were selected based on various criteria. A statistical analysis was carried out using the SPSS 21.0 program. Two versions of the analyses were used: a one-way ANOVA and a $t$-test for independent samples. The stocks categorized into the three simulations were identified, and portfolios A, B, and C were designed based on the selected stocks' analyses.

\section{Limitations and Calculations}

Due to its usefulness and transparency, the New York Stock Exchange (NYSE, 2013) database was used for data collection. Randomly selected stocks corresponding to the set filters were used; the movements of their prices were observed and then categorized into portfolios using the analytical methods.

Portfolio A comprises stocks selected based on the fundamental analysis indicators. The filters or selection criteria are the indexes of the fundamental analysis: $\mathrm{P} / \mathrm{E}<26.26$, $\mathrm{P} / \mathrm{B}<3.40, \mathrm{P} / \mathrm{S}<1.71$. The values represent the average of fundamental indicators of the S\&P 500 index on January 25, 2002. The numbers correspond to the current average of the S\&P index according to the Bloomberg filter.

Information from the database was considered from January 25, 2002, to December 31, 2012, as a long-term average.

Table 1 Selection of Stocks according to Fundamental Indicators

\begin{tabular}{|c|c|c|c|c|c|}
\hline Stock code (NYSE) & $\mathrm{P} / \mathrm{E}$ & $\mathrm{P} / \mathrm{B}$ & $\mathrm{P} / \mathrm{S}$ & $\begin{array}{l}\text { Price on } \\
25 / 1 / 2002\end{array}$ & $\begin{array}{c}\text { Price on } \\
31 / 12 / 2012\end{array}$ \\
\hline AEP-American Electric Power Company Inc. & 12.62 & 1.62 & 0.55 & 41.55 & 42.68 \\
\hline ALL-The Allstate Corp. & 16.11 & 1.34 & 0.80 & 32.40 & 40.17 \\
\hline CR-Crane Co. & 14.20 & 2.18 & 0.89 & 23.86 & 46.28 \\
\hline D-Dominion Resources, Inc. & 13.97 & 1.84 & 1.38 & 29.20 & 51.80 \\
\hline DUK-Duke Energy Corp. & 8.03 & 1.28 & 0.88 & 108.12 & 63.80 \\
\hline DVN-Devon Energy Corp. & 7.73 & 1.51 & 1.66 & 19.29 & 52.04 \\
\hline ETR-Entergy Corp. & 12.52 & 1.19 & 0.92 & 40.45 & 63.75 \\
\hline FMC-FMC Corp. & 11.25 & 2.94 & 0.55 & 8.64 & 58.52 \\
\hline HAL-Halliburton Company & 11.20 & 1.30 & 0.47 & 7.17 & 34.69 \\
\hline JCl-Johnson Controls, Inc. & 15.05 & 2.28 & 0.36 & 13.24 & 30.67 \\
\hline M-Macy's, Inc. & 11.20 & 1.34 & 0.49 & 20.20 & 39.02 \\
\hline NEE-NextEra Energy, Inc. & 11.34 & 1.63 & 1.12 & 26.81 & 69.19 \\
\hline NOC-Northrop Grumman Corp. & 15.89 & 1.39 & 0.61 & 52.40 & 67.58 \\
\hline PNW-Pinnacle West Capital Corp. & 10.62 & 1.43 & 0.91 & 42.50 & 50.98 \\
\hline PPL-PPL Corp. & 8.09 & 2.65 & 0.88 & 16.80 & 28.63 \\
\hline R-Ryder System, Inc. & 15.52 & 1.18 & 0.28 & 23.91 & 49.93 \\
\hline SVU-Supervalu, Inc. & 13.85 & 1.63 & 0.14 & 23.55 & 2.47 \\
\hline TAP-Molson Coors Brewing Company & 16.03 & 1.98 & 0.79 & 26.29 & 42.79 \\
\hline TE-TECO Energy, Inc. & 11.41 & 1.72 & 1.29 & 24.43 & 16.76 \\
\hline WMB-Williams Companies, Inc. & 9.81 & 1.72 & 0.43 & 24.77 & 32.74 \\
\hline
\end{tabular}

Source: S\&P 500, Bloomberg, NKBM 
Table 2 Selection of Stocks according to Technical Indicators

\begin{tabular}{|c|c|c|c|}
\hline Stock code (NYSE) & MACD on $25 / 1 / 2002$ & Price on $25 / 1 / 2002$ & Price on $31 / 12 / 2012$ \\
\hline AP-Ampco-Pittsburgh Corp. & 0.05 & 11.11 & 19.98 \\
\hline BAX-Baxter International, Inc. & 0.96 & 52.52 & 66.66 \\
\hline BHLB-Berkshire Hills Bancorp, Inc. & 0.71 & 21.59 & 23.86 \\
\hline CEC-CEC Entertainment, Inc. & 1.03 & 28.40 & 33.19 \\
\hline Cl-CIGNA Corp. & 0.08 & 31.10 & 53.46 \\
\hline CRT-Cross Timbers Royalty Trust & 0.45 & 18.70 & 26.92 \\
\hline EBF-Ennis, Inc. & 0.31 & 9.67 & 15.47 \\
\hline ETR-Entergy Corp. & 0.54 & 40.45 & 63.75 \\
\hline FNFG-First Niagara Fin. Group, Inc. & 0.25 & 6.90 & 7.93 \\
\hline GAS-AGL Resources, Inc. & 1.42 & 45.55 & 39.97 \\
\hline GSH-Guangshen Railway Co., Ltd. & 0.22 & 8.90 & 19.74 \\
\hline IDA-IDACORP, Inc. & 0.28 & 38.43 & 43.35 \\
\hline LMT-Lockheed Martin Corporation & 2.22 & 50.00 & 92.29 \\
\hline MRF-American Income Fund, Inc. & 0.04 & 8.71 & 8.37 \\
\hline MSB-Mesabi Trust & 0.03 & 3.14 & 25.45 \\
\hline PRE-Partnerre, Ltd. & 0.19 & 51.52 & 80.49 \\
\hline RCl-Rogers Communications, Inc. & 0.18 & 7.98 & 45.40 \\
\hline SCG-SCANA Corporation & 0.16 & 27.59 & 45.64 \\
\hline SQM-Sociedad Quimica y Minera de Chile & 0.08 & 2.18 & 57.64 \\
\hline WMT-Wal-Mart Stores, Inc. & 1.67 & 58.40 & 68.23 \\
\hline
\end{tabular}

Source: S\&P 500, Bloomberg, NKBM

The same source of information was used to select stocks for portfolio B, which consists of stocks analyzed using the technical analysis indicators of which only the following will be applied: MACD $>0$, RSI $<50$, Stochastic Buy Signal $<30$ days. These values are set theoretically according to Bloomberg. The relative strength index (RSI) is one of the most well-known technical indicators, which is why it was included in the criteria for selecting stocks for portfolio B. RSI focuses on the movement of the stock price and measures the ratio between the average surge and drop in the price of a stock. The stochastic oscillator compares the final price of the stock in relation to the interval of the stock's movement within a specified period of time. The MACD indicator, which proved to be the best indicator of the purchase or sale of stocks (Trančar, 2000), was chosen as the primary criterion. Whenever a signal line intersects the value 0 from the bottom to the top, it is time to buy the stock as it is expected that its value will go up in the future and vice versa. Based on this information, stocks whose MACD indicator value was either positive or close to zero and showed a rising value were included in portfolio B. The value of the MACD indicator for individual stocks was chosen on January 25, 2002, and the prices of all stocks were subsequently monitored.
Portfolio C consists of the best stocks of portfolios A and B. The primary criteria used were the MACD in the technical analysis and the $\mathrm{P} / \mathrm{E}$ in the fundamental analysis. thus, portfolio $\mathrm{C}$ represented the selection of stocks based on both fundamental and technical analyses. So as not to neglect any of them, we chose exactly one half of portfolio A and one half of portfolio B stocks. The first and the second simulations comprise portfolios of 10 stocks, while the third includes portfolios of 20 stocks.

After setting filters and selecting stocks for all three simulations, monthly stock prices were monitored from January 25, 2002, to December 31, 2012, for the first part and from January 27,2012, to December 12, 2012, for the second part.

Based on the hypotheses, we expected portfolio $\mathrm{C}$ to be more profitable in all simulations than portfolios $\mathrm{A}$ and $\mathrm{B}$ as portfolio C comprises portfolio A's stocks with the lowest P/E index and portfolio B's stocks where the MACD index is positive and close to zero. Table 1 summarizes the selection of the stocks; the values in all tables are expressed in U.S. dollars.

The results of monitoring all three simulations representing the three portfolios were based on different criteria. The first 
simulation represents the movement of the individual portfolios' values: portfolio A (10 stocks), selected using fundamental indicators; portfolio B (10 stocks), selected using technical indicators; and portfolio C (20 stocks), selected according to the combination of fundamental and technical analyses. The second simulation also comprises three portfolios consisting the second half of the chosen stocks. Using the same principle, the third simulation was designed, except the portfolios comprise the whole group of stocks. However, the portfolio always covers only one stock from an individual joint-stock company.

For portfolio A:

$A_{t}=P_{1_{t}}+P_{2_{t}}+\ldots+P_{n_{t}}=\sum_{i=1}^{n} P_{i_{t}}$

where,

$A_{t}=$ value of portfolio A at time $t$

$i=\{1,2,3, \ldots, \mathrm{n}\}$

$n=$ number of stocks included in portfolio A

$P_{i_{t}}=$ value of stock $i$ at time $t$

$t=$ time

What follows is the calculation of the profitability rate of portfolio A.

$\% \mathrm{~A}=\left(\frac{A_{t}-A_{t-1}}{A_{t-1}}\right) * 100$ in \%

where,

$\% \mathrm{~A}=$ profitability rate of portfolio A (in \%)

$A_{t} \quad=$ value of portfolio $\mathrm{A}$ at time $t$

$A_{t-1}=$ value of portfolio $\mathrm{A}$ at time $t-1$
Supposing that we ennoble our capital for 10 years and do not change portfolios $\mathrm{A}, \mathrm{B}$, or $\mathrm{C}$, the variable will be $t-1=$ $25 / 1 / 2002, t=31 / 12 / 2012$. The same methodology is used to calculate the value and profitability of portfolios B and C. Because we wanted to acquire realistic results of our simulations, we monitored the movement of stock prices for a period of 10 years, at the end of which the profitability of each portfolio was determined.

\section{Analysis and Results}

Table 3 shows the values (in U.S. dollars) and profitability of individual portfolios in each simulation.

Using the same methodology, 26 stocks were chosen for the three simulations from January 27, 2012, to December 27, 2012. If we ennoble our capital for only one year and do not change portfolios $\mathrm{A}, \mathrm{B}$, and $\mathrm{C}$, the variable is $t-1=27 / 1 / 2012$, $t=27 / 12 / 2012$. The same methodology was used to calculate the value and profitability of portfolios A, B, and C. Portfolio A comprises stocks selected using the fundamental analysis indicators: $\mathrm{P} / \mathrm{E}<13.35, \mathrm{P} / \mathrm{B}<2.15, \mathrm{P} / \mathrm{S}<1.29$. The values represent the average of fundamental indicators of the S\&P 500 index on January 27, 2012. The same methodology was used to calculate the value and profitability of portfolios A, $\mathrm{B}$, and $\mathrm{C}$. The values in Table 4 are expressed in U.S. dollars.

In addition, the statistical analysis carried out with the SPSS 21.0 program proved our hypothesis. Two versions of analyses were presented, with the results being the same in both of them. In the first version the one-way ANOVA (one-way analysis of version) was used; a $t$-test for independent samples was used in the second version. 
Table 3 Value and Profitability of Portfolios of Individual Simulations (10 years)

\begin{tabular}{|c|c|c|c|c|c|c|c|c|}
\hline \multicolumn{3}{|c|}{ SIMULATION 1 / PORTFOLIO A } & \multicolumn{3}{|c|}{ SIMULATION 1 / PORTFOLIO B } & \multicolumn{3}{|c|}{ SIMULATION 1 / PORTFOLIO C } \\
\hline Stock code & $25 / 1 / 2002$ & $31 / 12 / 2012$ & Stock code & $25 / 1 / 2002$ & $31 / 12 / 2012$ & Stock code & $25 / 1 / 2002$ & $31 / 12 / 12$ \\
\hline AEP & 41.55 & 42.68 & AP & 11.11 & 19.98 & DVN & 19.29 & 52.04 \\
\hline ALL & 32.40 & 40.17 & BAX & 52.52 & 66.66 & DUK & 108.12 & 63.8 \\
\hline $\mathrm{CR}$ & 23.86 & 46.28 & BHLB & 21.59 & 23.86 & HAL & 7.17 & 34.69 \\
\hline D & 29.20 & 51.80 & CEC & 28.40 & 33.19 & FMC & 8.64 & 58.52 \\
\hline DUK & 108.12 & 63.80 & $\mathrm{Cl}$ & 31.10 & 53.46 & ETR & 40.45 & 63.75 \\
\hline DVN & 19.29 & 52.04 & CRT & 18.70 & 26.92 & AP & 11.11 & 19.98 \\
\hline ETR & 40.45 & 63.75 & EBF & 9.67 & 15.47 & $\mathrm{Cl}$ & 31.1 & 53.46 \\
\hline FMC & 8.64 & 58.52 & ETR & 40.45 & 63.75 & FNFG & 6.9 & 7.93 \\
\hline HAL & 7.17 & 34.69 & FNFG & 6.90 & 7.93 & EBF & 9.67 & 15.47 \\
\hline $\mathrm{JCl}$ & 13.24 & 30.67 & GAS & 45.55 & 39.97 & CRT & 18.7 & 26.92 \\
\hline Value of portfolio & 323.92 & 484.40 & Value of portfolio & 265.99 & 351.19 & Value of portfolio & 261.15 & 396.56 \\
\hline Profitability & & $49.50 \%$ & Profitability & & $32.00 \%$ & Profitability & & $51.85 \%$ \\
\hline \multicolumn{3}{|c|}{ SIMULATION 2 / PORTFOLIO A } & \multicolumn{3}{|c|}{ SIMULATION 2 / PORTFOLIO B } & \multicolumn{3}{|c|}{ SIMULATION 2 / PORTFOLIO C } \\
\hline M & 20.20 & 39.02 & GSH & 8.90 & 19.74 & PPL & 16.80 & 28.63 \\
\hline NEE & 26.81 & 69.19 & IDA & 38.43 & 43.35 & WMB & 41.55 & 42.68 \\
\hline NOC & 52.40 & 67.58 & LMT & 50.00 & 92.29 & PNW & 42.50 & 50.98 \\
\hline PNW & 42.50 & 50.98 & MRF & 8.71 & 8.37 & M & 20.20 & 39.02 \\
\hline PPL & 16.80 & 28.63 & MSB & 3.14 & 25.45 & NEE & 26.81 & 69.19 \\
\hline$\underline{\mathrm{R}}$ & 23.91 & 49.93 & PRE & 51.52 & 80.49 & MSB & 3.14 & 25.45 \\
\hline SVU & 23.55 & 2.47 & $\mathrm{RCl}$ & 7.98 & 45.40 & MRF & 8.71 & 8.37 \\
\hline TAP & 26.29 & 42.79 & SCG & 27.59 & 45.64 & SQM & 2.18 & 57.64 \\
\hline TE & 24.43 & 16.76 & SQM & 2.18 & 57.64 & SCG & 27.59 & 45.64 \\
\hline WMB & 24.77 & 32.74 & WMT & 58.40 & 68.23 & $\mathrm{RCl}$ & 7.98 & 45.40 \\
\hline Value of portfolio & 281.66 & 400.09 & Value of portfolio & 256.85 & 486.60 & Value of portfolio & 197.46 & 413.00 \\
\hline Profitability & & $42.00 \%$ & Profitability & & $89.40 \%$ & Profitability & & $109.16 \%$ \\
\hline \multicolumn{3}{|c|}{ SIMULATION 3 / PORTFOLIO A } & \multicolumn{3}{|c|}{ SIMULATION 3 / PORTFOLIO B } & \multicolumn{3}{|c|}{ SIMULATION 3 / PORTFOLIO C } \\
\hline AEP & 41.55 & 42.68 & AP & 11.11 & 19.98 & DVN & 19.29 & 52.04 \\
\hline ALL & 32.40 & 40.17 & BAX & 52.52 & 66.66 & DUK & 108.12 & 63.8 \\
\hline $\mathrm{CR}$ & 23.86 & 46.28 & BHLB & 21.59 & 23.86 & PPL & 16.8 & 28.63 \\
\hline D & 29.20 & 51.80 & CEC & 28.40 & 33.19 & WMB & 41.55 & 42.68 \\
\hline DUK & 108.12 & 63.80 & $\mathrm{Cl}$ & 31.10 & 53.46 & PNW & 42.5 & 50.98 \\
\hline DVN & 19.29 & 52.04 & CRT & 18.70 & 26.92 & HAL & 7.17 & 34.69 \\
\hline ETR & 40.45 & 63.75 & EBF & 9.67 & 15.47 & $M$ & 20.2 & 39.02 \\
\hline FMC & 8.64 & 58.52 & ETR & 40.45 & 63.75 & FM & 8.64 & 58.52 \\
\hline HAL & 7.17 & 34.69 & FNFG & 6.90 & 7.93 & TE & 24.43 & 16.76 \\
\hline $\mathrm{JCl}$ & 13.24 & 30.67 & GAS & 45.55 & 39.97 & NEE & 26.81 & 69.19 \\
\hline$M$ & 20.20 & 39.02 & GSH & 8.90 & 19.74 & MSB & 3.14 & 25.45 \\
\hline NEE & 26.81 & 69.19 & IDA & 38.43 & 43.35 & MRF & 8.71 & 8.37 \\
\hline $\mathrm{NOC}$ & 52.40 & 67.58 & LMT & 50.00 & 92.29 & AP & 11.11 & 19.98 \\
\hline PNW & 42.50 & 50.98 & MRF & 8.71 & 8.37 & $\mathrm{Cl}$ & 31.1 & 53.46 \\
\hline PPL & 16.80 & 28.63 & MSB & 3.14 & 25.45 & SQM & 2.18 & 57.64 \\
\hline$R$ & 23.91 & 49.93 & PRE & 51.52 & 80.49 & SCG & 27.59 & 45.64 \\
\hline
\end{tabular}




\begin{tabular}{|c|c|c|c|c|c|c|c|c|}
\hline \multicolumn{3}{|c|}{ SIMULATION 3 / PORTFOLIO A } & \multicolumn{3}{|c|}{ SIMULATION 3 / PORTFOLIO B } & \multicolumn{3}{|c|}{ SIMULATION 3 / PORTFOLIO C } \\
\hline Stock code & $25 / 1 / 2002$ & $31 / 12 / 2012$ & Stock code & $25 / 1 / 2002$ & $31 / 12 / 2012$ & Stock code & $25 / 1 / 2002$ & $31 / 12 / 12$ \\
\hline SVU & 23.55 & 2.47 & $\mathrm{RCl}$ & 7.98 & 45.40 & PRE & 51.52 & 80.49 \\
\hline TAP & 26.29 & 42.79 & SCG & 27.59 & 45.64 & $\mathrm{RCl}$ & 7.98 & 45.4 \\
\hline TE & 24.43 & 16.76 & SQM & 2.18 & 57.64 & GSH & 8.9 & 19.74 \\
\hline WMB & 24.77 & 32.74 & WMT & 58.40 & 68.23 & FNFG & 6.9 & 7.93 \\
\hline Value of portfolio & 605.58 & 884.49 & Value of portfolio & 522.84 & 837.79 & Value of portfolio & 474.64 & 820.41 \\
\hline Profitability & & $46.00 \%$ & Profitability & & $60.20 \%$ & Profitability & & $72.85 \%$ \\
\hline
\end{tabular}

Source: NYSE, NKBM, author's calculations

Table 4 Value and Profitability of Portfolios of Individual Simulations (one year)

\begin{tabular}{|c|c|c|c|c|c|c|c|c|}
\hline \multicolumn{3}{|c|}{ SIMULATION 1 / PORTFOLIO A } & \multicolumn{3}{|c|}{ SIMULATION 1 / PORTFOLIO B } & \multicolumn{3}{|c|}{ SIMULATION 1 / PORTFOLIO C } \\
\hline Stock code & $27 / 1 / 2012$ & $27 / 12 / 2012$ & Stock code & 27/1/2012 & $27 / 12 / 2012$ & Stock code & $27 / 1 / 2012$ & 27/12/2012 \\
\hline ADM & 29.82 & 27.49 & AA & 10.43 & 8.62 & BAC & 7.29 & 11.47 \\
\hline $\mathrm{AET}$ & 43.43 & 46.24 & ACE & 69.46 & 79.62 & ADM & 29.82 & 27.49 \\
\hline AFL & 49.04 & 53.01 & AET & 43.43 & 46.24 & AFL & 49.04 & 53.01 \\
\hline $\mathrm{BAC}$ & 7.29 & 11.47 & AMGN & 68.34 & 86.15 & $\mathrm{CVX}$ & 103.96 & 108.52 \\
\hline C & 30.87 & 39.25 & AMT & 63.01 & 76.29 & COP & 52.9 & 57.9 \\
\hline $\mathrm{CHK}$ & 22.05 & 16.86 & APD & 88.19 & 84.80 & $\mathrm{C}$ & 30.87 & 39.25 \\
\hline $\mathrm{Cl}$ & 45.18 & 53.66 & BDX & 79.09 & 78.28 & AET & 43.43 & 46.24 \\
\hline COP & 52.90 & 57.90 & BMY & 32.29 & 32.14 & AMT & 63.01 & 76.29 \\
\hline CVX & 103.96 & 108.52 & BXP & 104.24 & 105.67 & $\mathrm{AA}$ & 10.43 & 8.62 \\
\hline ETN & 49.57 & 53.63 & CAT & 111.28 & 87.66 & AMGN & 68.34 & 86.15 \\
\hline FE & 42.26 & 41.65 & EMR & 51.67 & 52.67 & BDX & 79.09 & 78.28 \\
\hline GD & 70.35 & 69.02 & FDX & 92.95 & 91.50 & HNZ & 51.73 & 57.86 \\
\hline HES & 55.26 & 52.45 & FLR & 57.23 & 58.20 & BMY & 32.29 & 32.14 \\
\hline HUM & 88.26 & 68.00 & HNZ & 51.73 & 57.86 & EMR & 51.67 & 52.67 \\
\hline Value of portfolio & 690.25 & 699.15 & Value of portfolio & 923.34 & 945.70 & Value of portfolio & 673.87 & 735.89 \\
\hline Profitability & & $1.29 \%$ & Profitability & & $2.42 \%$ & Profitability & & $9.20 \%$ \\
\hline \multicolumn{3}{|c|}{ SIMULATION 2 / PORTFOLIO A } & \multicolumn{3}{|c|}{ SIMULATION 2 / PORTFOLIO B } & \multicolumn{3}{|c|}{ SIMULATION 2 / PORTFOLIO C } \\
\hline MET & 35.52 & 32.88 & INTU & 57.35 & 60.34 & VLO & 24.12 & 33.83 \\
\hline MRO & 31.24 & 30.32 & KSS & 46.69 & 42.54 & MET & 35.52 & 32.88 \\
\hline MUR & 61.42 & 59.47 & MDLZ & 25.17 & 25.36 & NOC & 58.71 & 67.74 \\
\hline NOC & 58.71 & 67.74 & MON & 80.53 & 93.99 & RTN & 48.64 & 57.8 \\
\hline PCG & 40.83 & 40.02 & NOV & 77.40 & 66.97 & $\mathrm{XRX}$ & 7.88 & 6.79 \\
\hline PRU & 57.22 & 53.05 & NUE & 44.50 & 43.15 & WLP & 65.42 & 60.48 \\
\hline RTN & 48.64 & 57.80 & PXD & 97.42 & 104.95 & NUE & 44.5 & 43.15 \\
\hline TEL & 34.30 & 36.93 & ROK & 76.90 & 82.74 & MDLZ & 25.17 & 25.36 \\
\hline$\underline{\text { UNH }}$ & 51.02 & 54.44 & SNDK & 46.70 & 43.22 & SWN & 32.04 & 33.13 \\
\hline VLO & 24.12 & 33.83 & SWN & 32.04 & 33.13 & KSS & 46.69 & 42.54 \\
\hline WLP & 65.42 & 60.48 & TEL & 34.30 & 36.93 & MON & 80.53 & 93.99 \\
\hline $\mathrm{XRX}$ & 7.88 & 6.79 & XOM & 85.83 & 86.86 & PXD & 97.42 & 104.95 \\
\hline Value of portfolio & 516.32 & 533.75 & Value of portfolio & 704.83 & 720.18 & Value of portfolio & 566.64 & 602.64 \\
\hline Profitability & & $3.37 \%$ & Profitability & & $2.17 \%$ & \%Profitability & & $6.30 \%$ \\
\hline
\end{tabular}




\begin{tabular}{|c|c|c|c|c|c|c|c|c|}
\hline \multicolumn{3}{|c|}{ SIMULATION 3 / PORTFOLIO A } & \multicolumn{3}{|c|}{ SIMULATION 3 / PORTFOLIO B } & \multicolumn{3}{|c|}{ SIMULATION 3 / PORTFOLIO C } \\
\hline ADM & 29.82 & 27.49 & $\mathrm{AA}$ & 10.43 & 8.62 & VLO & 24.12 & 33.83 \\
\hline AET & 43.43 & 46.24 & ACE & 69.46 & 79.62 & BAC & 7.29 & 11.47 \\
\hline AFL & 49.04 & 53.01 & AET & 43.43 & 46.24 & ADM & 29.82 & 27.49 \\
\hline BAC & 7.29 & 11.47 & AMGN & 68.34 & 86.15 & AFL & 49.04 & 53.01 \\
\hline C & 30.87 & 39.25 & AMT & 63.01 & 76.29 & CVX & 103.96 & 108.52 \\
\hline $\mathrm{CHK}$ & 22.05 & 16.86 & APD & 88.19 & 84.80 & COP & 52.9 & 57.9 \\
\hline $\mathrm{Cl}$ & 45.18 & 53.66 & $\mathrm{BDX}$ & 79.09 & 78.28 & MET & 35.52 & 32.88 \\
\hline COP & 52.90 & 57.90 & BMY & 32.29 & 32.14 & $\mathrm{C}$ & 30.87 & 39.25 \\
\hline CVX & 103.96 & 108.52 & BXP & 104.24 & 105.67 & NOC & 58.71 & 67.74 \\
\hline ETN & 49.57 & 53.63 & CAT & 111.28 & 87.66 & AET & 43.43 & 46.24 \\
\hline $\mathrm{FE}$ & 42.26 & 41.65 & EMR & 51.67 & 52.67 & $\mathrm{Cl}$ & 45.18 & 53.66 \\
\hline GD & 70.35 & 69.02 & FDX & 92.95 & 91.50 & RTN & 48.64 & 57.8 \\
\hline HES & 55.26 & 52.45 & FLR & 57.23 & 58.20 & $\mathrm{XRX}$ & 7.88 & 6.79 \\
\hline HUM & 88.26 & 68.00 & HNZ & 51.73 & 57.86 & NUE & 44.5 & 43.15 \\
\hline MET & 35.52 & 32.88 & INTU & 57.35 & 60.34 & AMT & 63.01 & 76.29 \\
\hline MRO & 31.24 & 30.32 & KSS & 46.69 & 42.54 & $\mathrm{AA}$ & 10.43 & 8.62 \\
\hline MUR & 61.42 & 59.47 & MDLZ & 25.17 & 25.36 & MDLZ & 25.17 & 25.36 \\
\hline NOC & 58.71 & 67.74 & MON & 80.53 & 93.99 & SWN & 32.04 & 33.13 \\
\hline PCG & 40.83 & 40.02 & NOV & 77.40 & 66.97 & KSS & 46.69 & 42.54 \\
\hline PRU & 57.22 & 53.05 & NUE & 44.50 & 43.15 & AMGN & 68.34 & 86.15 \\
\hline RTN & 48.64 & 57.80 & PXD & 97.42 & 104.95 & MON & 80.53 & 93.99 \\
\hline TEL & 34.30 & 36.93 & ROK & 76.90 & 82.74 & BDX & 79.09 & 78.28 \\
\hline UNH & 51.02 & 54.44 & SNDK & 46.70 & 43.22 & PXD & 97.42 & 104.95 \\
\hline VLO & 24.12 & 33.83 & SWN & 32.04 & 33.13 & HNZ & 51.73 & 57.86 \\
\hline WLP & 65.42 & 60.48 & TEL & 34.30 & 36.93 & BMY & 32.29 & 32.14 \\
\hline $\mathrm{XRX}$ & 7.88 & 6.79 & XOM & 85.83 & 86.86 & XOM & 85.83 & 86.86 \\
\hline Value of portfolio & 1206.57 & 1232.90 & Value of portfolio & 1628.17 & 1665.88 & Value of portfolio & 1254.43 & 1365.9 \\
\hline Profitability & & $2.12 \%$ & Profitability & & 2.319 & \%Profitability & & $8.88 \%$ \\
\hline
\end{tabular}

Source: NYSE, NKBM, author's calculations

Table 5 ANOVAa

\begin{tabular}{|c|c|c|c|c|c|c|c|c|}
\hline \multicolumn{9}{|c|}{ Descriptives ${ }^{\mathrm{a}}$ in $\%$} \\
\hline \multirow{2}{*}{$a-10$ years } & \multirow{2}{*}{$\mathrm{N}$} & \multirow{2}{*}{ Mean } & \multirow{2}{*}{ Std. Deviation } & \multirow{2}{*}{ Std. Error } & \multicolumn{2}{|c|}{ 95\% Confidence Interval for Mean } & \multirow{2}{*}{ Minimum } & \multirow{2}{*}{ Maximum } \\
\hline & & & & & Lower Bound & Upper Bound & & \\
\hline $\mathrm{A}$ & 3 & 45.8333 & 3.75278 & 2.16667 & 36.5109 & 55.1557 & 42.00 & 49.50 \\
\hline B & 3 & 60.5333 & 28.70145 & 16.57079 & -10.7650 & 131.8317 & 32.00 & 89.40 \\
\hline$\underline{\mathrm{C}}$ & 3 & 77.9533 & 28.99383 & 16.73959 & 5.9287 & 149.9780 & 51.85 & 109.16 \\
\hline Total & 9 & 61.4400 & 24.76953 & 8.25651 & 42.4005 & 80.4795 & 32.00 & 109.16 \\
\hline \multicolumn{9}{|c|}{ ANOVA $^{\mathrm{a}}$ in $\%$} \\
\hline \multicolumn{4}{|c|}{ Sum of Squares } & df & Mean Square & $\mathrm{F}$ & Sig. & \\
\hline \multicolumn{2}{|c|}{ Between Groups } & 1551.241 & & 2 & 775.620 & 1.386 & 0.320 & \\
\hline \multicolumn{2}{|c|}{ Within Groups } & 3356.997 & & 6 & 559.500 & & & \\
\hline \multicolumn{2}{|l|}{ Total } & 4908.238 & & 8 & & & & \\
\hline
\end{tabular}


Table 6 Post Hoc Tests

\begin{tabular}{|c|c|c|c|c|c|c|}
\hline \multicolumn{2}{|c|}{ a-10 years } & \multicolumn{5}{|c|}{ Multiple Comparisons ${ }^{a}$} \\
\hline \multicolumn{7}{|c|}{ Dependent Variable: in \% } \\
\hline \multicolumn{7}{|l|}{ Bonferroni } \\
\hline \multirow{2}{*}{ (I) portfolio } & \multirow{2}{*}{ (J) portfolio } & \multirow{2}{*}{$\begin{array}{l}\text { Mean Difference } \\
(I-J)\end{array}$} & \multirow{2}{*}{ Std. Error } & \multirow{2}{*}{ Sig. } & \multicolumn{2}{|c|}{ 95\% Confidence Interval } \\
\hline & & & & & Lower Bound & Upper Bound \\
\hline \multirow{2}{*}{$A$} & B & -14.70000 & 19.31320 & 1.000 & -78.1913 & 48.7913 \\
\hline & C & -32.12000 & 19.31320 & 0.442 & -95.6113 & 31.3713 \\
\hline \multirow{2}{*}{ B } & $\mathrm{A}$ & 14.70000 & 19.31320 & 1.000 & -48.7913 & 78.1913 \\
\hline & C & -17.42000 & 19.31320 & 1.000 & -80.9113 & 46.0713 \\
\hline \multirow{2}{*}{ C } & $\mathrm{A}$ & 32.12000 & 19.31320 & 0.442 & -31.3713 & 95.6113 \\
\hline & B & 17.42000 & 19.31320 & 1.000 & -46.0713 & 80.9113 \\
\hline
\end{tabular}

*. The mean difference is significant at the 0.05 level.

Table 7 Independent Samples Test ${ }^{\mathrm{a}} \mathrm{A}-\mathrm{C}$

\begin{tabular}{|c|c|c|c|c|c|c|c|c|c|}
\hline \multicolumn{10}{|c|}{ Independent Samples Test ${ }^{\mathrm{a}}$ in \% } \\
\hline \multirow{3}{*}{ a-10 years } & \multicolumn{3}{|c|}{$\begin{array}{l}\text { Levene's Test for } \\
\text { Equality of Variances }\end{array}$} & \multicolumn{6}{|c|}{$t$-test for Equality of Means } \\
\hline & \multirow[t]{2}{*}{$\mathrm{F}$} & \multirow[t]{2}{*}{ Sig. } & \multirow[t]{2}{*}{$t$} & \multirow[t]{2}{*}{ df } & \multirow{2}{*}{$\begin{array}{c}\text { Sig. } \\
\text { (2-tailed) }\end{array}$} & \multirow{2}{*}{$\begin{array}{c}\text { Mean } \\
\text { Difference }\end{array}$} & \multirow{2}{*}{$\begin{array}{l}\text { Std. Error } \\
\text { Difference }\end{array}$} & \multicolumn{2}{|c|}{$\begin{array}{l}\text { 95\% Confidence Interval } \\
\text { of the Difference }\end{array}$} \\
\hline & & & & & & & & Lower & Upper \\
\hline $\begin{array}{l}\text { Equal variances } \\
\text { assumed }\end{array}$ & 5.105 & 0.087 & -1.903 & 4 & 0.130 & -32.12000 & 16.87923 & -78.98426 & 14.74426 \\
\hline $\begin{array}{l}\text { Equal variances } \\
\text { not assumed }\end{array}$ & & & -1.903 & 2.067 & 0.193 & -32.12000 & 16.87923 & -102.53577 & 38.29577 \\
\hline
\end{tabular}

Table 8 Independent Samples Test ${ }^{\mathrm{a}} \mathrm{B}-\mathrm{C}$

\begin{tabular}{|c|c|c|c|c|c|c|c|c|c|}
\hline \multicolumn{10}{|c|}{ Independent Samples Test ${ }^{a}$} \\
\hline \multirow{3}{*}{ a-10 years } & \multicolumn{3}{|c|}{$\begin{array}{l}\text { Levene's Test for } \\
\text { Equality of Variances }\end{array}$} & \multicolumn{4}{|c|}{$t$-test for Equality of Means } & & \\
\hline & \multirow{2}{*}{$\mathrm{F}$} & \multirow{2}{*}{ Sig. } & \multirow{2}{*}{$t$} & \multirow{2}{*}{ df } & \multirow{2}{*}{$\begin{array}{c}\text { Sig. } \\
\text { (2-tailed) }\end{array}$} & \multirow{2}{*}{$\begin{array}{c}\text { Mean } \\
\text { Difference }\end{array}$} & \multirow{2}{*}{$\begin{array}{l}\text { Std. Error } \\
\text { Difference }\end{array}$} & \multicolumn{2}{|c|}{$\begin{array}{l}\text { 95\% Confidence Interval } \\
\text { of the Difference }\end{array}$} \\
\hline & & & & & & & & Lower & Upper \\
\hline $\begin{array}{l}\text { Equal variances } \\
\text { assumed }\end{array}$ & 0.016 & 0.906 & -0.740 & 4 & 0.501 & -17.42000 & 23.55430 & -82.81723 & 47.97723 \\
\hline $\begin{array}{l}\text { Equal variances } \\
\text { not assumed }\end{array}$ & & & -0.740 & 4.000 & 0.501 & -17.42000 & 23.55430 & -82.81987 & 47.97987 \\
\hline
\end{tabular}

As Tables 5 through 8 demonstrate, among the three portfolios, no statistically significant differences occur at the 0.05 level of significance, which means that the differences are not statistically important. Nevertheless, the profitability of portfolio $\mathrm{C}$ is, on average, $32.12 \%$ greater than the profitability of portfolio A over 10 years (i.e., 3.21\% a year) $17.42 \%$ greater than the profitability of portfolio B (i.e., $1.74 \%$ a year). 
Tables 9 through 12 summarize the results of the statistical analyses of stocks' profitability when held for only one year.

Table 9 ANOVA $^{a}$

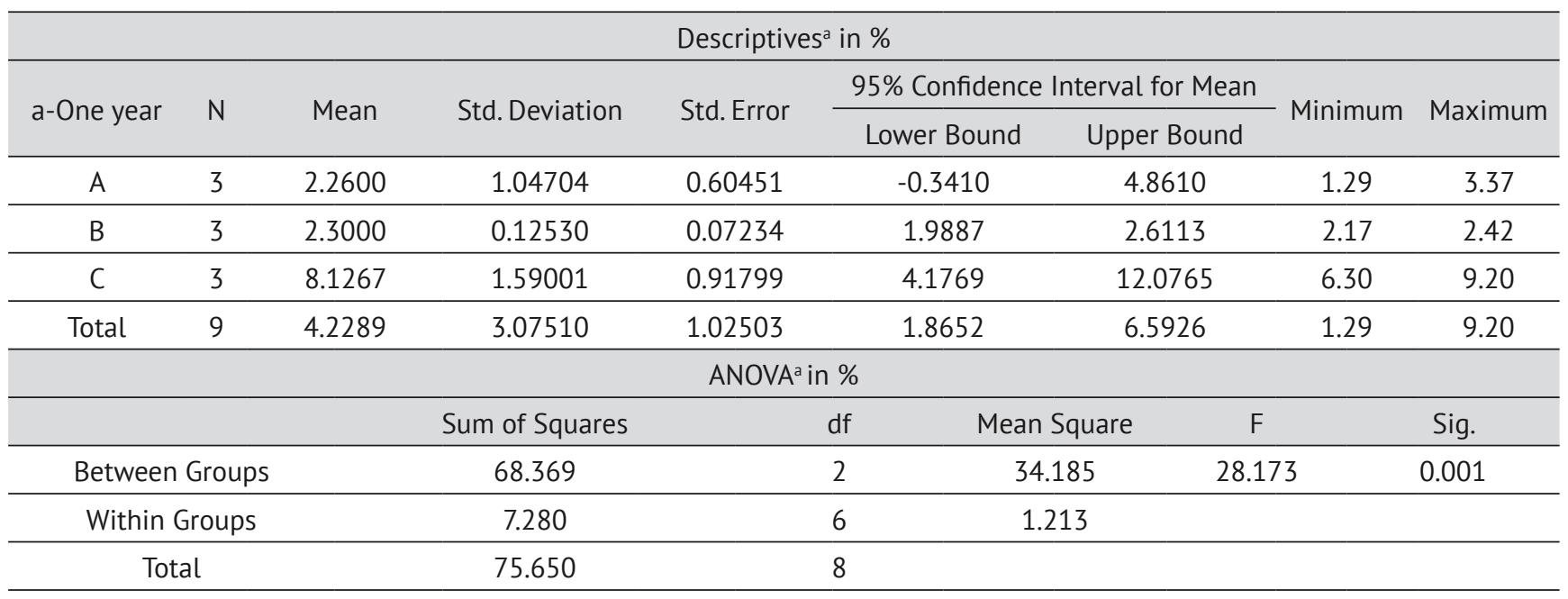

Table 10 Post Hoc Testsa

\begin{tabular}{|c|c|c|c|c|c|c|}
\hline a-One year & & Multiple Comparisons ${ }^{a}$ & & & & \\
\hline \multicolumn{7}{|c|}{ Dependent Variable: in \% } \\
\hline \multicolumn{7}{|l|}{ Bonferroni } \\
\hline \multirow{2}{*}{ (I) portfolio } & \multirow{2}{*}{ (J) portfolio } & \multirow{2}{*}{ Mean Difference (I-J) } & \multirow{2}{*}{ Std. Error } & \multirow{2}{*}{ Sig. } & \multicolumn{2}{|c|}{ 95\% Confidence Interval } \\
\hline & & & & & Lower Bound & Upper Bound \\
\hline \multirow{2}{*}{$A$} & $\mathrm{~B}$ & -0.04000 & 0.89940 & 1.000 & -2.9967 & 2.9167 \\
\hline & $\mathrm{C}$ & $-5.86667^{*}$ & 0.89940 & 0.002 & -8.8234 & -2.9099 \\
\hline \multirow{2}{*}{ B } & A & 0.04000 & 0.89940 & 1.000 & -2.9167 & 2.9967 \\
\hline & C & $-5.82667^{*}$ & 0.89940 & 0.002 & -8.7834 & -2.8699 \\
\hline \multirow{2}{*}{$\mathrm{C}$} & $A$ & $5.86667^{*}$ & 0.89940 & 0.002 & 2.9099 & 8.8234 \\
\hline & $B$ & $5.82667^{*}$ & 0.89940 & 0.002 & 2.8699 & 8.7834 \\
\hline
\end{tabular}

Table 11 Independent Samples Test ${ }^{\mathrm{a}} \mathrm{A}-\mathrm{C}$

\begin{tabular}{|c|c|c|c|c|c|c|c|c|c|}
\hline \multicolumn{10}{|c|}{ Independent Samples Test ${ }^{\mathrm{a}}$ in \% } \\
\hline \multirow{3}{*}{ a-One year } & \multicolumn{4}{|c|}{$\begin{array}{l}\text { Levene's Test for } \\
\text { Equality of Variances }\end{array}$} & \multicolumn{3}{|c|}{$t$-test for Equality of Means } & & \\
\hline & \multirow[t]{2}{*}{$\mathrm{F}$} & \multirow{2}{*}{ Sig. } & \multirow{2}{*}{$t$} & \multirow{2}{*}{ df } & \multirow{2}{*}{ Sig. (2-tailed) } & \multirow{2}{*}{$\begin{array}{l}\text { Mean } \\
\text { Difference }\end{array}$} & \multirow{2}{*}{$\begin{array}{l}\text { Std. Error } \\
\text { Difference }\end{array}$} & \multicolumn{2}{|c|}{$\begin{array}{l}95 \% \text { Confidence Interval of } \\
\text { the Difference }\end{array}$} \\
\hline & & & & & & & & Lower & Upper \\
\hline $\begin{array}{l}\text { Equal variances } \\
\text { assumed }\end{array}$ & 1.184 & 0.338 & -5.337 & 4 & 0.006 & -5.86667 & 1.09916 & -8.91841 & -2.81492 \\
\hline $\begin{array}{l}\text { Equal variances } \\
\text { not assumed }\end{array}$ & & & -5.337 & 3.460 & 0.009 & -5.86667 & 1.09916 & -9.11574 & -2.61759 \\
\hline
\end{tabular}


Table 12 Independent Samples Test ${ }^{\mathrm{a}} \mathrm{B}-\mathrm{C}$

\begin{tabular}{cccccccccc}
\hline & \multicolumn{3}{c}{$\begin{array}{c}\text { Levene's Test for } \\
\text { Equality of Variances }\end{array}$} \\
\cline { 2 - 10 } a-One year & F & Sig. & $t$ & df & $\begin{array}{c}\text { Sig. } \\
\text { (2-tailed) }\end{array}$ & $\begin{array}{c}\text { Mean } \\
\text { Difference }\end{array}$ & $\begin{array}{c}\text { Std. Error } \\
\text { Difference }\end{array}$ & $\begin{array}{c}\text { 95\% Confidence Interval } \\
\text { of the Difference }\end{array}$ \\
\hline $\begin{array}{c}\text { Equal variances } \\
\text { assumed }\end{array}$ & 12.458 & 0.024 & -6.328 & 4 & 0.003 & -5.82667 & 0.92084 & -8.38333 & -3.27001 \\
\hline $\begin{array}{c}\text { Equal variances } \\
\text { not assumed }\end{array}$ & & & -6.328 & 2.025 & 0.023 & -5.82667 & 0.92084 & -9.74250 & -1.91083 \\
\hline
\end{tabular}

According to Tables 9 through 12, among the three portfolios, there are statistically significant differences at the 0.001 level of significance. The profitability of portfolio $\mathrm{C}$ is on average statistically significantly bigger than the profitability of portfolio A (i.e., by 5.87\%) and the profitability of portfolio B (i.e., by 5.83\%). In addition, the statistical results show that, in terms of the stock analysis, it is reasonable to use and choose the right combination of indicators of both types of stock analysis - fundamental and technical-as doing so enables the reduction of risks in asset management.

Nevertheless, we are aware of the fact that the verification of the hypothesis is connected with the risk of obtaining different results as the result is dependent on the selection of indicators, the chosen time period, stock selection for joint portfolios, and other factors.

\section{Conclusions}

Regarding the design of investment portfolios, the most frequently used methods of stock analysis are fundamental and technical analyses, which analyze economic, structural, and political factors influencing the development of market capital. The main focus of this view is analyzing the numerous data of a conjunctive nature as well as the indicators of economic trends, structural factors, the effects of labor market flexibility, political decisions, and the like. Although the latter focuses mainly on the history of the monitored stocks' value, it favors methodology that indicates that it is possible to predict the stock movement in the future with the help of its past graphical forms. The flexibility of the stock analyses, indicators, and principles used is mainly dependent on the model chosen by the analyst or portfolio manager. In principle, each analytical method is only as flexible as its analyst or portfolio manager, who is definitely aware of the fact that both analyses have positive and negative sides and therefore should be combined by using the former to determine which stock to choose and the latter to determine when it is the right time to buy.

However, we still have not answered the questions of how many and which indicators to choose for individual stock analyses. If many false indicators are used, the model for predicting the stock's movement will also be false. Even a very skilled investor is not capable of indefinitely studying a great number of indicators.

The point of designing a model is to define not only the right number of chosen indicators, but also the right ones. If we choose too many indicators, the model will not bring the wanted synergetic effects as individual indicators can interfere with each other. This results in the phenomenon where each individual indicator shows a better prognosis of stock price movement than all the indicators together. Therefore, it is incorrect to monitor individual indicators in isolation as it leads to one indicator's weakness equaling the potential power of predicting the stock price movement of another one (Heese, 2011). For this reason, portfolio managers' analysts should find an appropriate set of complementary indicators that can then be used to design a valid model. The accuracy of predicting the stock price movement will increase; consequently, the probability of portfolio outcomes coming true will also increase.

In conclusion, let us briefly review the empirical conclusions from the research, which was based on three simulations, comprising portfolios $\mathrm{A}, \mathrm{B}$, and $\mathrm{C}$. The average of fundamental indicators for S\&P 500 index on a specific day's filters was the basis for selecting stock according to the primary criteria. Among the known criteria (i.e., $\mathrm{P} / \mathrm{E}$, $\mathrm{P} / \mathrm{S}$, and $\mathrm{P} / \mathrm{B}$ ), $\mathrm{P} / \mathrm{E}$ was selected as the primary filter for the selection of stocks for portfolios A and C.

Regarding technical indicators, our choice was limited to MACD, RSI, and stochastic buy signal. The MACD index was chosen for the categorization of portfolios B and C. 
Due to its usefulness and transparency, the NYSE database was used for the data collection. Randomly selected stocks corresponding to the set filters were used; movements of the prices were observed and then categorized into portfolios with the help of analytical methods.

The results of the portfolios' analysis led to the following conclusions. The profitability of portfolio A (comprised stocks selected based on fundamental indicators) and B (designed with the help of technical analysis criteria) was in all simulations lower than the profitability of portfolio C. Due to the combinations of both stocks' analyses, a better filter was chosen for the selection of stocks for portfolio C than for portfolios A and B. It is possible that the combination of different indicators from the fundamental and technical analyses had an influence on the profitability of the portfolio. The combined use of indicators from both technical and fundamental analyses of stocks had a positive impact on the profitability of the portfolio.

The answer to the question as to whether such results can be expected on other stock markets as well as would be affirmative as the profitability of the portfolio is more dependent on a positive economic situation, macro and micro economic factors, investment period, investment dispersion, and similar location as the market in which we invested.

Yet compared to the European market, the American market has by its nature a larger number of business operations, greater liquidity, and a broader choice of investment products (Mai, 2004). A better allocation of capital is ensured by unified business conditions, which enable the investors to invest their capital into the investments that they expect to yield the best results (Baele et al., 2004). A concentration of capital markets ends up in de facto unified national regulations and supervision. In addition, the market capitalization of American stock markets is twice as large as all European stock markets combined. Thus, dealing with stocks on various national stock exchanges on the European market causes bigger transaction costs, which leads investors to concentrate primarily on home securities (Mai, 2004). In addition, Jensen (1978) stressed the importance of trading profitability in assessing market efficiency. He further highlighted the importance of transactions costs and other market microstructure issues for defining market efficiency (Schwert, 2002).

All of these considerations lead to the assumption that the American capital market is more effective, which is not true according to Fama (1970; 1991), whose hypothesis of an effective market is based on the presumption that the prices of securities contain all the available and relevant information and that all participants on the market-buyers as well as sellers - act rationally. Thus, all market information is at any time reflected in the rates. According to the theory of market efficiency, no market participant can, in the long-term, outrun the market (Fama, 1970). Our model of portfolio formation rejects all three major components of Fama's hypothesis of weak efficiency, which states that we cannot draw conclusions about the future of stock rates from past rate movements (Steiner \& Bruns, 2000). The technical analysis of stocks is mostly based on the past movements of stock rates, which-according to defenders of this approach-gives good results in terms of moderate efficiency, which claims that all markets' important and public information is incorporated into the actual rate itself. Fama (1970) concluded that the basic analysis is useless, as all public information is already included into the actual rate itself (Scheufele \& Haas, 2008). Meanwhile, high efficiency refers to the claim that all markets' relevant public and internal information is reflected in the rate; thus, the use of insider information on the financial market-especially in stock exchange business - is useless. The fact that doing business on the stock exchange using insider information is lucrative in the short term also rejects this hypothesis (Scheufele \& Haas, 2008; Steiner \& Bruns, 2000), just as it is rejected by our model of portfolio selection.

Ultimately, the chosen stock selection model can be used for the American or any other capital market. It is essential that the basic data reflect the actual state of the company and the economy as a whole, especially as there are as many portfolio formation models as there are portfolio managers and investors creating their own models. 


\section{References}

1. Baele, L., Baele, L., Ferrando, A., Hördahl, P., Krylova, E., \& Monnet, C. (2004). Measuring European financial integration. Oxford Review of Economic Policy, 20(4), 509-530. http://dx.doi.org/10.1093/oxrep/grh030

2. Baker, H. K. (2010). Behavioural finance, investors, corporations, and markets. Hoboken, NJ: John Wiley \& Sons. http://dx.doi. org/10.1002/9781118258415

3. Bazdan, Z. (2010). Sell when the violins are playing-Buy when the cannons rumble. Case Study: Technical analysis and chartists. Naše gospodarstvo, 3-4, 11-18.

4. Born, K. (2009). Intelligente Kapitalanlage. Durch Aktienanalyse zum langfristigen Börsenerfolg. Wien: Linde Verlag.

5. Braun, J. (2007). Fundamentalanalyse, technische Analyse und Behavioral Finance. Saarbrücken: VDM, Müller Verlag.

6. Budelmann, T., C. (2013). Portfolio-Gastbeitrag: Mehrwert durch systematische Aktienselektion. Börsen-Zeitung, $38,2$.

7. Ellmann, F. (2006). Finanzierungsform von Analysen muss klar erkennbar sein. Börsen-Zeitung, 96, 8.

8. Fama, E. F. (1970). Efficient capital markets. A review of theory and empirical work. Journal of Finance, 25(2), 383. http://dx.doi. org/10.1111/j.1540-6261.1970.tb00518.x

9. Fama, E. F. (1991). Efficient capital market II. Journal of Finance, 46(5), 1575-1617.

10. http://dx.doi.org/10.1111/j.1540-6261.1991.tb04636.x

11. Goldberg J., \& von Nitzsch, R. (2004). Behavioural finance: Gewinnen mit Kompetenz. München: Finanz Buch-Verlag.

12. Graham, B. (2009). Modri investitor z dodanimi komentarji Jasona Zweiga. Ljubljana: Soleco.

13. Han, Y., Yang, K., \& Zhou, G. (2013). A new anomaly: The cross-sectional profitability of technical analysis. Journal of Financial \& Quantitative Analysis, 48(5), 33-35. http://dx.doi.org/10.1017/S0022109013000586

14. Heese, V. (2011). Aktienbewertung mit Kennzahlen, Kurschancen und risiken fundiert beurteilen. Wiesbaden: Gabler Verlag. http://dx.doi. org/10.1007/978-3-8349-6446-5

15. Jensen, M. C. (1978). Some anomalous evidence regarding market efficiency. Journal of Financial Economics, 95-102. http://dx.doi. org/10.1016/0304-405X(78)90025-9

16. Kleindienst, R. (2001). Varčevanje v domačih in tujih delnicah: najboljša pot za doseganje dolgoročnih finančnih ciljev. Ljubljana:Založba GV.

17. Knight, T. (2007). Chart your way to profits. The online trader's guide to technical analysis. New York: John Wiley and Sons, Inc.

18. Madura, J. (2011). Financial markets and institutions. Mason Ohio: South-Western Cengage Learning.

19. Mai, H. (2004). Effizienterer US-Finanzmarkt. Deutsche Bank Research. Retreived from http://www.dbresearch.de

20. Matschke, M. J., \& Brösel, G. (2013). Unternehmensbewertung: Funktionen-Methoden-Grundsätze. Wiesbaden: Springer Fachmedien. http://dx.doi.org/10.1007/978-3-8349-4053-7

21. Mattern, C. (2005). Fundamentalanalyse im Portfoliomanagement. Konjunkturindikatoren verstehen und analysieren. Stuttgart: SchäfferPoeschel Verlag.

22. Nison, S. (2001). Japanese candlestick charting techniques: A contemporary guide to the ancient investment techniques of Far East. New York: New York Institute of Finance.

23. NYSE. (2013). Database: Bloomberg, KBM Infond, d.o.o. \& NYSE. Retrieved from https://nyse.nyx.com \& http://www.bloomberg.com/ markets/stocks/

24. Pernsteiner, H. (2008). Finanzmanagement Aktuell: Unternehmensfinanzierung, Wertpapier-management, Kapitalmarkt, Bank-Versicherung. Wien: Linde Verlag.

25. Scheufele B., \& Haas, A. (2008). Medien und Aktien, Springer VS. Verlag für Sozialwissenschaften, 16-27.

26. Schwert, G. W. (2002). Anomalies and market efficiency. Chapter 15 in Handbook of the Economics of Finance. (NBER Working Paper No. W9277, 4-5)

27. Steiner, M., \& Bruns, C. (2008). Wertpapiermanagement: Professionelle Wertpapieranalyse und Portfoliostrukturierung. Stuttgart: Schäffer-Poeschel Verlag.

28. Trančar, V. (2000). Tehnična analiza delnic in njena uporaba v praksi. Magistrsko delo. Maribor: Ekonomsko-poslovna fakulteta.

29. Welcker, J., \& Audörsch, J. (1994). Technische Aktienanalyse. Zürich: MI Verlag.

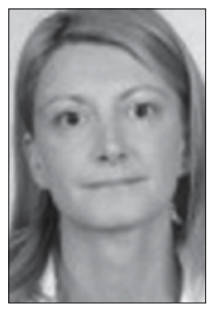

Vesna Trančar graduated from the Faculty of Economics and Business in Maribor in 1995 and was employed in Comtron, Ltd., a computer company, in Maribor from 1995 to 1996. Since then, she has worked at the School Centre in Ptuj. She completed her teaching and adult education exams (1997), professional examinations (1999), and MBA in corporate finance and banking from the Faculty of Economics and Business in Maribor (2000). She participated in the stock market seminar at the Faculty of Economics and Business in Maribor in 2006 and completed her professional examinations on the Administrative Procedure Act in 2007. Since 2008, she has been the head of the school development team and a member of the expert group for the school's development projects. 


\section{Vpliv kombinacije različnih metod analiz delnic na donosnost portfelja}

\section{Izvleček}

V literaturi, v kateri so bile proučevane analize delnic, se pogosto srečujemo z istimi vprašanji: Katero od naštetih analiz delnic izbrati, kateri kazalniki posamezne analize delnic dajejo najboljše informacije o tem, ali določeno delnico vključiti v portfelj ali ne? Koliko kazalnikov in katero kombinacijo med njimi izbrati, da bodo napovedi prihodnjega gibanja cen delnic čim bolj natančne? Ali lahko investitorji z analizami delnic oblikujejo takšen portfelj, da bo izpolnil njihova naložbena pričakovanja? Glavni namen članka je, da z metodologijo, ki smo jo predstavili v teoretičnem delu, preverimo, ali uporaba kombinacije kazalnikov različnih analiz delnic pozitivno vpliva na donosnost portfelja ali ne.

Ključne besede: portfelj, analiza portfelja delnic, upravljavec portfelja, kazalniki analiz delnic, investicijsko odločanje, cena delnice 